\title{
PENGARUH PENERAPAN E-SPT, PENGETAHUAN DAN SOSIALISASI PERPAJAKAN TERHADAP KEPATUHAN WAJIB PAJAK ORANG PRIBADI
}

\section{THE EFFECT OF E-SPT IMPLEMENTATION, KNOWLEDGE AND TAX SOCIALIZATION ON PERSONAL TAX COMPLIANCE}

\author{
Hadian Wibowo ${ }^{1}$, Endang Mahpudin ${ }^{2}$ \\ Universitas Singaperbangsa Karawang, Indonesia ${ }^{1,2}$ \\ 1610631030127@student.unsika.ac.id ${ }^{1,2}$
}

\begin{abstract}
This research aims to find out and test the influence of E-SPT Implementation, Knowledge and Socialization on Personal Taxpayer Compliance in TelukJambe Village. The study used quantitative methods using primary data obtained from questionnaires. The population in the study was 620 people. The sample in this study was 86 respondents. The sampling technique used is Purposive Sampling. The results showed that the Implementation of E-SPT had no significant effect on Taxpayer Compliance, Knowledge had a significant effect on Taxpayer Compliance and Socialization had no significant effect on People's Taxpayer Compliance. The influence of E-spt, Knowledge and Socialization together affects Taxpayer Compliance.
\end{abstract}

Keywords: Implementation of E-SPT, Knowledge and Socialization, Taxpayer Compliance.

\begin{abstract}
ABSTRAK
Penelitian ini bertujuan untuk mengetahui dan menguji pengaruh Penerapan E-SPT, Pengetahuan dan Sosialisasi terhadap Kepatuhan Wajib Pajak Orang Pribadi pada Desa TelukJambe. Penelitian ini menggunakan metode kuantitatif dengan menggunakan data primer yang diperoleh dari kuesioner. Populasi dalam penelitian ini sebanyak 620 orang. Sampel dalam penelitian ini sebanyak 86 responden. Teknik pengambilan sampel yang digunakan adalah Purposive Sampling. Hasil penelitian menunjukkan bahwa Penerapan E-SPT tidak berpengaruh signifikan terhadap Kepatuhan Wajib Pajak, Pengetahuan berpengaruh signifikan terhadap Kepatuhan Wajib Pajak dan Sosialiasi tidak berpengaruh signifikan terhadap Kepatuhan Wajib Pajak Orang. Pengaruh E-spt, Pengetahuan dan Sosialisasi secara bersama-sama berpengaruh terhadap Kepatuhan Wajib Pajak.
\end{abstract}

Kata Kunci: Penerapan E-SPT, Pengetahuan dan Sosialisasi, Kepatuhan Wajib Pajak.

\section{PENDAHULUAN}

Pemerintah mengikutsertakan masyarakat dalam pembiayaan keuangan negara melalui pemungutan pajak. Pajak adalah iuran rakyat kepada kas Negara berdasarkan undang-undang yang dapat dipaksakan dengan tiada mendapat jasa timbal (kotraprestasi) yang langsung dapat ditunjukkan dan yang di gunakan untuk membayar pengeluaran umum (Mardiasmo, 2011).

Lembaga negara yang ditunjuk oleh pemerintah sebagai lembaga pengelola pajak yaitu Direktorat Jenderal Pajak (DJP). Sebagai lembaga pengelola pajak, DJP melakukan beberapa 
reformasi dan inovasi sitem administratif demi meningkatkan pendapatan negara dari sektor pajak. Perubahan ini dimaksudkan untuk menumbuhkan kepercayaan masyarakat terhadap pemungut pajak dan inovasi yang dilakukan. Menyikapi perkembangan tersebut DJP Direktur Jenderal Pajak menyampaikan Keputusan Direktur Jenderal Pajak Nomor KEP-88/PJ./2004 tanggal 14 Mei 2004 (BN No. 7069 hal. 4B) tentang Penyampaian Surat Pemberitahuan secara Elektronik e-SPT (Sari, 2015)

Peran pajak dalam meningkatkan pembangunan diberbagai sektor kehidupan tentu tidak dapat dipungkiri namun tidak banyak rakyat yang menyadari hal tersebut dikarenakan manfaat dari pelayanan pajak tidak langsung diterima, namun tidak bisa dipungkiri bahwa saat ini hampir seluruh masyarakat telah memperoleh manfaat pajak seperti pelayanan kesehatan gratis, pendidikan gratis, akses transprotasi dan mobilitas yang mudah melalui pembangunan infrasturktur jalan yang mendorong perekonomian. Untuk meningkatkan kepatuhan wajib pajak ada faktor lain yang mempengaruhinya yaitu biaya kepatuhan pajak, dalam melaksanakan biaya kepatuhan wajib pajak harus mengeluarkan biaya yang sudah dikenakan kepada masyarakat ,namun hal ini akan menyebabkan masyarakat tidak patuh dalam melaksanakan wajib pajak. (Pajakku.com).

Salah satu dasar penerimaan pajak sesuai target adalah kepatuhan wajib pajak. Kepatuhan wajib pajak adalah kondisi dimana wajib pajak memenuhi kewajiban perpajakannya dan melaksanakan hak perpajakannya. Kepatuhan wajib pajak yang baik adalah akan dilihat dari keteraturannya untuk menyetorkan pajak.
Dengan adanya kepatuhan dari wajib pajak diharapkan wajib pajak berusaha untuk memenuhi peraturan hukum perpajakan yang berlaku, baik memenuhi kewajiban ataupun melaksanakan hak perpajakannya. Keuntungan kepatuhan wajib pajak antara lain kepatuhan dalam mendaftarkan diri, tepat waktu dalam menyampaikan SPT untuk semua jenis pajak, menghitung dan membayar pajak.

Dalam penyampaian SPT secara elektonik ini merupakan upaya dari Direktorat Jenderal Pajak (DJP) untuk memberikan kemudahan pelayanan bagi wajib pajak untuk melaporkan jumlah pajak yang tadinya harus dibayarkan secara langsung ke Kantor Pelayanan Pajak (KPP), sekarang masyarakat bisa membayarnya tanpa datang ke kantor palayanan pajak untuk memenuhi kewajiban perpajakannya dalam hal menghitung jumlah pajak terhutangnya. Sedangkan bagi pegawai pajak, teknologi e-SPT memudahkan dalam mengelola database karena penyimpanan dokumen-dokumen wajib pajak telah dilakukan dalam bentuk digital (Sari, 2015)

Saat ini teknologi membuat segalanya semakin nyaman dan mudah, masyarakat tidak ada alasan merasakan beban untuk pemenuhan kewajiban surat pemberitahuan (SPT) menurut UndangUndang nomor 16 tahun 2009 mengenai KUP Pasal 1 angka 11 dan peraturan menteri keuangan nomor 152/PMK.03/2009 adalah surat wajib pajak digunakan untuk melaporkan perhitungan atau pembayaran pajak, objek pajak atau bukan objek pajak, harta dan kewajiban sesuai dengan ketentuan peraturan perUndang Undangan perpajakan (Suharsono, 2015).

Hasil penelitian menyimpulkan bahwa hasil penelitian menunjukan bahwa Penerapan e-Spt dan e-Filling di 
KPP Pratama Manado mengalami peningkatan jumlah pengguna tiap tahunnya, kepatuhan wajib pajak yaitu ketepatan waktu melapor pajak menggunakan E-spt dan e-Filling pun mengalami peningkatan dari tahun 2013 dengan tahun pajak 2012 sampai tahun 2015 dengan tahun pajak 2014 dan kepatuhan wajib pajak sebelum dan sesudah penerapan e-Filling meningkat setiap tahunnya sehingga dapat disimpulkan penerapan e-Spt dan eFilling berhasil meningkatkan kepatuhan wajib pajak dalam menyampaikan Spt tahunan di KPP Pratama Manado.

Berdasarkan studi literature , penelitian untuk melakukan efisiensi kewajiban pajak melalui sistem e-SPT ini tidak semudah yang dipikirkan. Misalnya adanya kesulitan yang dialami oleh wajib pajak untuk memasukkan data dokumen perpajakannya karena belum memahami sepenuhnya mengenai mekanisme penyampaian dan pengoperasian SPT pajak secara elektronik tersebut. Kesadaran dan kepatuhan subjek pajak sangat diperlukan dalam mendukung pelaksanaan penerapan e-SPT guna melunasi utang pajaknya dengan baik dan benar.

Ketidak patuhan wajib pajak ini dipengaruhi oleh beberapa faktor diantaranya, kurangnya kesadaran dan kepedulian wajib pajak untuk memenuhi kewajiban perpajakannya yang sesuai dengan peraturan perpajakannya yang sesuai dengan peraturan perpajakannya. Kepatuhan wajib pajak dapat dipengaruhi oleh beberapa faktor, baik faktor eksternal maupun faktor internal. Salah satu faktor eskternal yang dapat mempengaruhi kepatuhan wajib pajak orang pribadi adalah sosialisasi perpajakan, sedangkan faktor internalnya adalah pengetahuan perpajakan.

Sosialisasi perpajakan berarti suatu upaya yang dilakukan untuk memberikan informasi mengenai perpajakan yang bertujuan agar seseorang ataupun kelompok paham tentang perpajakan sehingga kepatuhan wajib pajak akan meningkat. Jika wajib pajak diberikan pemahaman yang baik dan benar melalui sosialisasi, maka wajib akan memiliki pengetahuan tentang pentingnya membayar pajak.

Hal ini didukung dengan penelitian Tumuli, et.al (2015) menemukan sosialisasi perpajakan yang insentif dapat meningkatkan pengetahuan calon wajib pajak mengenai semua hal yang berkaitan dengan perpajakan. Penelitian Tene, et.al (2017) menyatakan sosialiasasi perpajakan berpengaruh signifikan terhadap pengetahuan perpajakan wajib pajak. Tanpa adanya sosialisasi yang efektif kepada wajib pajak, maka wajib pajak akan kesulitan dalam memenuhi kewajiban perpajakannya.

Bedasarkan permasalahan dari studi literature tersebut maka dari itu perlu dilakukan penelitian Pengaruh penerapan E-spt, penggetahuan dan sosialisasi perpajak terhadap kepatuhan wajib pajak orang pribadi dalam melaporkan spt.

\section{METODE PENELITIAN}

Metode deskriptif dan metode verifikasi. Penelitian deskriptif adalah penelitian yang digunakan untuk menjawab rumusan masalah yang berkenaan dengan pertanyaan terhadap keberadaan variabel mandiri, baik hanya pada satu variabel atau lebih. Melalui penelitian deskriptif maka dapat diperoleh deskriptif dari rumusan masalah yang pertama Bagaimana Penerapan e-SPT di desa Telukjambe di wilayah KPP Karawang Utara, kedua Seberapa besar pengaruh pengetahuan perpajakan pada desa TelukJambe yang berada wilayah KPP Karawang Utara, ketiga Apakah sosialisasi perpajakan 
berpengaruh terhadap kepatuhan wajib pajak di desa Telukjambe yang berada di wilayah KPP Karawang Utara.

Selain penelitian deskriptif, penulis pun menggunakan penelitian verifikatif. Metode verifikatif metode memperlihatkan pengaruh dari variabelvariabel yang digunakan untuk menguji hipotesis dengan menggunakan perhitungan statistic. Penelitian verifikatif adalah suatu penelitian yang ditujukan untuk menguji teori, dan mencoba menghasilkan metode ilmiah yakni status hipotesis yang berupa kesimpulan, apakah suatu hipotesis diterima atau ditolak, Sugiyono (2015). Penelitian verifikatif digunakan untuk menjawab perumusan masalah keempat Apakah ada pengaruh signifikan antara pengaruh penerapan e-spt , pengetahuan dan sosialisasi perpajakan terhadap tinglat kepatuhan wajib pajak di desa telukjambe yang berada di wilayah KPP Karawang Utara.

\section{HASIL DAN PEMBAHASAN Uji Validitas dan Reliabilitas}

Berdasarkan nilai koefisien korelasi dengan menggunakan bantuan software SPSS versi 21 diperoleh hasil bahwa variabel pada penelitian ini valid dan reliabel. Hasil tersebut dibuktikan dari nilai koefisien korelasir hasil lebih besar dari 0,3 mempunyai taraf signifikan dibawah atau sama dengan $0,05(\alpha \leq 0,05)$ dan nilai alpha lebih besar dari 0,6 .

\section{Uji Asumsi Klasik}

\section{Uji Normalitas Data}

Uji normalitas pada penelitian ini dilakukan dengan Kolmogorov-Smirnov Test dan diperoleh hasil data pada penelitian ini berdistribusi normal. Hasil tersebut dibuktikan dengan nilai signifikansi sebagai berikut:
Tabel 1 Tabel Hasil Uji Normalitas

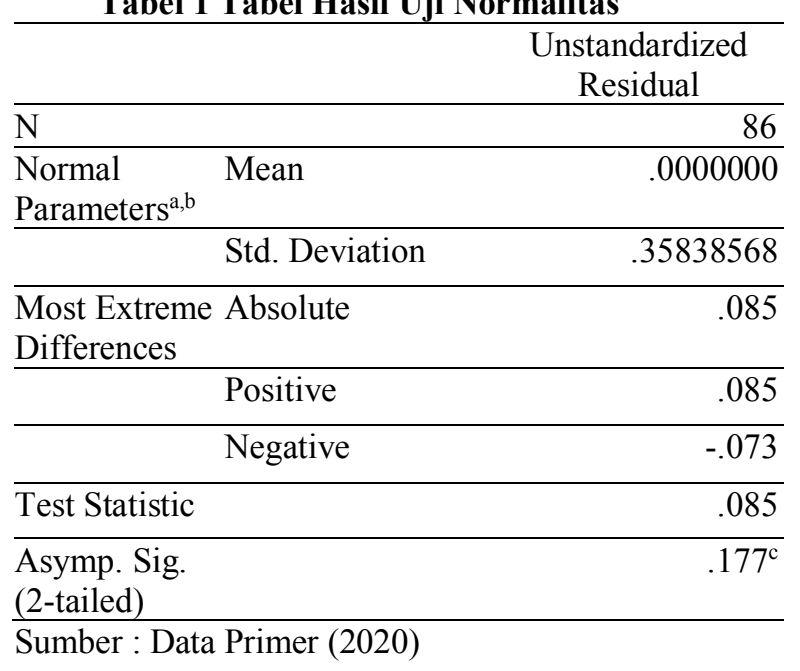

\section{Uji Multikolinieritas}

Tabel 2 Hasil Uji Multikolineritas

\begin{tabular}{llll}
\hline & \multicolumn{3}{c}{ Collinearity Statistics } \\
\cline { 2 - 4 } Model & \multicolumn{2}{c}{ Tolerance } & VIF \\
\hline SQRT_X1 & .408 & 2.453 \\
\hline Transform_x2 & .269 & 3.713 \\
\hline Transform_x3 & .419 & 2.389 \\
\hline
\end{tabular}

Sumber : Data Primer (2020)

Hasil uji multikolinieritas nilai VIF pada variabel bebas kurang dari 10, model regresi pada penelitian ini baik dan tidakditemukan adanya korelasi antar variabel bebas.

\section{Uji Heteroskesdastisitas}

Uji glesjer dilihat dengan cara menghasilkan regresi nilai absolute residual (AbsUi) terhadap variabel independen lainnya. Hasil dari uji glesjer pada penelitian ini ditunjukan pada tabel dibawah ini

Tabel 3 Uji Glesjer

\begin{tabular}{llllll} 
& & \multicolumn{2}{c}{$\begin{array}{l}\text { Unstandardized } \\
\text { Coefficients }\end{array}$} & & \\
\cline { 2 - 4 } Model & $\mathrm{B}$ & $\begin{array}{c}\text { Std. } \\
\text { Error }\end{array}$ & $\mathrm{T}$ & Sig. \\
& & & \\
\hline 1 Constant $)$ & .330 & .377 & .875 & .387 \\
\hline SQRT X1 & .077 & .096 & .808 & .424 \\
\hline Transform x2 & .086 & .573 & .150 & .881 \\
\hline Transform x3 & -.282 & .396 & -.710 & .482 \\
\hline Sumber : Data Primer $(2020)$ & & &
\end{tabular}


Berdasarkan data hasil Uji glesjer di atas dapat diartikan bahwa di dalam analisis regregsi tidak terdapat gejala heterokodesitas, menunujukan nilai signifikan ( $\mathrm{p}$-value) variabel Penerapan Espt sebesar 0,424, variabel Pengetahuan 0,881 dan Sosialisasi 0,482. Hasil tersebut dengan jelas menunjukan bahwa tidak ada satupun variabel independen yang signifikan secara statistic mempengaruhi variabel dependen nilai ABS_RES, hal tersebut dikarenakan nilai profitabilitas signifikasinya diatas 0,05 atau $5 \%$.

\section{Analisis Verifikatif}

Analisis verifikatif merupakan bentuk analisis model dan pembuktian yang dapat berguna untuk mencari kebenaran dari hipotesis yang diajukan dalam penelitian. Dalam penelitian ini, analisis statistik verivikatif digunakan dengan maksud untuk mengetahui hasil dari penelitian yang memiliki kaitan dengan pengaruh penerapan espt,pengetahuan,sosialisasi dan kepatuhan wajib pajak.

Dengan melakukan pengumpulan data menggunakan nilai statistik yang terdiri dari analisis korelasi, analisis regresi linier berganda, analisis korelasi dan analisis determinasi.

Tabel 4 Identitas Responden

\begin{tabular}{cccc}
\hline & Keterangan & Frekuensi & Persentase \\
\hline Jenis & Pria & 37 & $43 \%$ \\
\cline { 2 - 4 } Kelamin & Wanita & 49 & $57 \%$ \\
\cline { 2 - 4 } & Grand Total & 86 & $100 \%$ \\
\hline Pendidika & SMA & 25 & $29 \%$ \\
\cline { 2 - 4 } & $\mathrm{D} 3$ & 18 & $21 \%$ \\
\cline { 2 - 4 } & $\mathrm{S} 1$ & 38 & $44 \%$ \\
\cline { 2 - 4 } & $\mathrm{S} 2$ & 4 & $5 \%$ \\
\cline { 2 - 4 } & S 3 & 1 & $1 \%$ \\
\hline Usia & $20-30$ Tahun & 30 & $35 \%$ \\
\cline { 2 - 4 } & $31-40$ Tahun & 14 & $16 \%$ \\
\cline { 2 - 4 } & G1-50 Tahun & 12 & $14 \%$ \\
\cline { 2 - 4 } & $\begin{array}{c}\text { Diatas 50 } \\
\text { tahun }\end{array}$ & 30 & $35 \%$ \\
\cline { 2 - 4 } & Grand Total & 86 & $100 \%$ \\
\hline
\end{tabular}

Sumber : Data Primer (2020)

\section{Analisis Regresi Liniear Berganda}

Peneliti melakukan pengolahan data dengan memanfaatkan software SPSS, dan berikut diperoleh hasIl regresi linear berganda sebagai berikut :

\section{Tabel 5 Liniear Berganda}

\begin{tabular}{|c|c|c|c|c|c|}
\hline \multirow[b]{2}{*}{ Model } & \multicolumn{3}{|c|}{$\begin{array}{l}\text { Standardized } \\
\text { Unstandardized Coefficients } \\
\text { Coefficients }\end{array}$} & \multirow[b]{2}{*}{$\mathrm{T}$} & \multirow[b]{2}{*}{ Sig. } \\
\hline & B & $\begin{array}{c}\text { Std. } \\
\text { Error }\end{array}$ & Beta & & \\
\hline (Constant) & .730 & .420 & & 1.738 & .086 \\
\hline SQRT_X1 & .447 & .101 & .338 & 4.415 & .000 \\
\hline $\begin{array}{l}\text { Transform } \\
\text { x }\end{array}$ & .964 & .568 & .160 & 1.698 & .093 \\
\hline $\begin{array}{l}\text { Transform } \\
\text { x3 }\end{array}$ & 2.326 & .350 & .503 & 6.654 & .000 \\
\hline
\end{tabular}

Sumber : Data Primer (2020)

\section{Persamaan Regresi}

Dari tabel output SPSS diatas, terlihat nilai linear berganda pada kolom (B) Unstandardized Coefficients, jika dibuat model regresi linear berganda maka persamaannya sebagai berikut : $\mathrm{Y}=0,730+0,447 \mathrm{X} 1+0,964 \mathrm{X} 2+2,326$ $\mathrm{X} 3$

Keterangan:

Y1 : Kepatuhan Wajib Pajak

$\mathrm{X} 1$ : Penerapan Espt

$\mathrm{X} 2$ : Pengetahuan

$\mathrm{X} 3$ : Sosialisasi

Pada persamaan tersebut dapat dilihat masing-masing variabel bebas pada penelitian ini berpengaruh positif terhadap variabel terikat.

\section{Koefisien Determinasi}

Tabel 6 Koefisien Determinasi

\begin{tabular}{|c|c|c|c|c|}
\hline & & & $\begin{array}{l}\text { Adjusted Std. Error } \\
\text { R Square of }\end{array}$ & $\begin{array}{c}\text { Durbin } \\
-\end{array}$ \\
\hline Model & $\mathrm{R}$ & $\begin{array}{c}\mathrm{R} \\
\text { Square }\end{array}$ & Estimate & Watson \\
\hline 1 & $.898^{\mathrm{a}}$ & .807 & 3.084 & 1.821 \\
\hline
\end{tabular}

Tabel diatas, nilai koefisien determinasi yang diperoleh adalah 0,807 atau $80,7 \%$. Hasil tersebut menunjukan 
bahwa efektivitas Penerapan E-spt (X1) Pengetahuan (X2) dan Sosialisasi (X3) meberikan pengaruh sebesar 80,7\% terhadap Kepatuhan Wajib Pajak (Y). Sedangkan sebanyak 19,3\% merupakan peranan yang diberikan oleh faktor lain yang tidak diteliti dalam penelitian ini.

Berdasarkan uji hipotesis dengan menggunakan software SPSS versi 22.0 for windows dapat diketahui bahwa secara simultan dan parsial variabel pengaruh penerapan e-spt, pengaruh pengetahuan perpajakan terhadap kepatuhan wajib pajak dan sosialisasi yang berpengaruh signifikan terhadap kepatuhan wajib pajak orang pribadi. Berikut pembahasan hasil pengujian hipotesis akan dijelaskan sebagai berikut:

\section{Pengaruh Penerapan E-SPT terhadap Kepatuhan Wajib Pajak Orang Pribadi dalam Melaporkan SPT.}

Penerapan E-spt berpengaruh positif dan tidak signifikan terhadap kepatuhan wajib pajak yang berada di desa Telukjambe, tidak berpengaruhnya e-SPT terhadap Kepatuhan Wajib Pajak ini dikarenakan sebagian wajib pajak beranggapan bahwa menyampaikan SPT tahunan terlalu rumit terutama bagi mereka yang tidak mengetahui undangundang perpajakan yang mengatur besarnya pajak terutang yang harus dibayar oleh wajib pajak. Banyak wajib pajak tidak mau tahu kewajiban setelah mempunyai NPWP (Nomor Pokok Wajib Pajak). Hal ini dikarenakan wajib pajak merasa keberatan untuk membayar pajak. Saat ini banyak masyarakat yang telah mendaftarkan diri sebagai wajib pajak dan mendapat NPWP karena untuk memudahkan atau sebagai salah satu syarat untuk meminjam uang yang diperbankan atau instansi lainnya wajib mempunyai NPWP, tetapi wajib pajak kurang memahami bahwa setelah memiliki NPWP, mereka tidak boleh lalai untuk melakukan pernyampaian SPT dan membayar pajak.

Penelitian ini sejalan dengan Kertahadi \& Handayani, (2015) Survei pada Perkantoran Sunrise Garden di Wilayah Kedoya Jakarta Barat menemukan tidak berpengaruh signifikan terhadap kepatuhan wajib pajak karena meskipun e-spt sudah mudah digunakan tetapi belum efisien bagi wajib pajak sehingga kepatuhan wajib pajak bisa mengalami kenaikan atau penurun.

Dan penelitian ini sejalan dengan Warowu, et.al, (2015) di KPP Wilayah Jakarta Selatan menemukan tidak berpengaruh signifikan. Karena tidak berpengaruhnya e-SPT terhadap Kepatuhan Wajib Pajak ini dikarenakan sebagian wajib pajak beranggapan bahwa menyampaikan SPT tahunan terlalu rumit terutama bagi mereka yang tidak mengetahui undang-undang perpajakan yang mengatur besarnya pajak terutang yang harus dibayar oleh wajib pajak.

Namun hasil penelitian ini tidak sejalan dengan Pratami, et.al, (2017) di KPP Singosari menemukan bahwa sistem e-spt berpengaruh signifikan terhadap kepatuhan wajib pajak Penerapan e-SPT yang dinilai dapat meningkatkan kepatuhan wajib pajak tidak lepas dari peran DJP yang melakukan sosialisasi secara meluas mengenai e-SPT. Sosialisasi tersebut bertujuan agar wajib pajak mengetahui manfaat dan tujuan penerapan e-SPT. Sosialisasi mengenai e-SPT secara meluas juga mempunyai maksud untuk membuat wajib pajak cenderung lebih termotivasi untuk menggunakan e-SPT dari pada menggunakan SPT manual.

Dan penelitian ini tidak sejalan dengan penelitian Kertahadi \& Handayani (2015) yaitu penerapan eSPT berpengaruh secara signifikan terhadap kepatuhan pajak. Pentingnya 
peran e-SPT baik dari sisi wajib pajak maupun DJP sehingga sistem ini dituntut untuk memberikan kualitas penerapan sistem yang baik, semakin baik penerapan sistem e-SPT akan berpengaruh dalam meningkatkan kepatuhan wajib pajak.

\section{Pengaruh Pengetahuan terhadap Kepatuhan Wajib Pajak Orang Pribadi dalam Melaporkan SPT .}

Pengetahuan perpajakan berpengaruh positif dan signifikan terhadap kepatuhan wajib pajak di desa telukjambe, sehingga informasi pajak yang dapat digunakan wajib pajak sebagai dasar bertindak, mengambil keputusan, dan untuk menempuh arah atau strategi tertentu sehubungan dengan pelaksanaan hak dan kewajibannya di bidang perpajakan terbukti berpengaruh terhadap kepatuhan wajib pajak di desa telukjambe.

Hasil penelitian menunjukan bahwa wajib pajak mengetahui tentang ketentuan umum dan tata cara perpajakan dengan baik. Wajib pajak mengetahui fungsi perpajakan dengan baik. Wajib pajak mengetahui tentang sistem perpajakan di Indonesia dengan baik terbukti berpengaruh terhadap kepatuhan wajib pajak.

Pengetahuan tentang peraturan pajak sangat penting untuk menumbuhkan perilaku patuh. Karena bagaimana mungkin wajib pajak patuh apabila mereka tidak mengetahui bagaimana peraturan perpajakannya. Dengan adanya pengetahuan wajib pajak tentang pajak yang baik akan dapat memperkecil tax evasion(pengelapan pajak). Sebagian besar wajib pajak memperoleh pengetahuan tentang pajak dari petugas pajak. Ada juga yang diperoleh dari radio, televise, majalah, surat kabar, internet, buku perpajakan dan seminar pajak.
Hasil ini sejalan dengan penelitian Anjarwati \& Robiyanto (2017) di KPP Pratama Bandung menyatakan bahwa pengetahuan perpajakan mempunyai pengaruh secara signifikan positif terhadap kepatuhan wajib pajak karena pengetahuan perpajakan sangat penting untuk wajib pajak, tanpa pengetahuan perpajakan wajib pajak tidak akan melaporkan/membayarkan pajaknya. Dalam hal ini wajib pajak bisa mengalami peningkatan.

Dan Sejalan dengan penelitian Anjarwati \& Robiyanto (2017) di KPP Yogyakarta menyatakan bahwa pengetahuan perpajakan mempunyai pengaruh secara signifikan terhadap kepatuhan wajib pajak karena apabila wajib pajak sudah mengetahui pengetahuan tentang pajak maka wajib pajak cenderung berprilaku patuh dalam melaksanakan kewajiban perpajakannya. Namun hasil penelitian ini tidak sejalan dengan penelitian yang dilakukan Pratami, et.al (2017) KPP Pratama Pati yang menyatakan bahwa pengetahuan perpajakan tidak berpengaruh signifikan terhadap kepatuhan wajib pajak dan penelitian karena apabila wajib pajak memiliki pengetahuan yang cukup luas tentang pentingnya membayar pajak tetapi tidak memiliki keinginan untuk membayar pajak maka wajib pajak tidak akan patuh terhadap kewajiban perpajakannya.

Dan tidak sejalan dengan penelitian (Warouw, 2017) di KPP Pasuruan menyatakan bahwa pengetahuan perpajakan tidak berpengaruh signifikan terhadap kepatuhan wajib pajak karena pengetahuan perpajakan yang dimiliki dari latar belakang pendidikan wajib pajak tidak menjamin bahwa wajib pajak akan lebih patuh dalam melaksanakan kewajiban perpajakannya. Oleh karena itu diharapkan pemerintah atau petugas 
pajak memberikan kegiatan yang dapat memberikan pengetahuan terkait perpajakan kepada wajib pajak baik melalui sosialisasi atau penyuluhan maupun melalui media agar wajib pajak dapat memahami dengan betul tentang perpajakan yang pada akhirnya akan meningkatkan kepatuhan wajib pajak.

\section{Pengaruh Sosialisasi Perpajakan terhadap Kepatuhan Wajib Pajak Orang Pribadi Dalam Melaporkan SPT.}

Sosialisasi perpajakan berpengaruh positif dan tidak signifikan terhadap kepatuhan wajib pajak. Sebagian besar telah mengetahui adanya sosialisasi perpajakan baik secara langsung maupun tidak langsung dan mengikuti sosialisasi serta memperoleh informasi perpajakan melalui sosialisasi tersebut. Namun, sosialisasi perpajakan yang baik belum tentu dapat mempengaruhi kepatuhan Wajib Pajak Orang Pribadi. Hal tersebut disebabkan karena Wajib Pajak tidak dapat memahami dengan baik materi atau informasi perpajakan yang disampaikan oleh KPP dan karena materi atau informasi perpajakan tidak bersifat detail.

Ketidakpahaman responden atau Wajib Pajak terhadap materi atau informasi perpajakan yang disampaikan dapat disebabkan karena jumlah Wajib Pajak yang mengikuti sosialisasi langsung tersebut cukup banyak sehingga materi atau informasi perpajakan yang disampaikan tidak dapat tersampaikan dengan baik secara menyeluruh kepada para Wajib Pajak dengan kata lain sosialisasi tersebut tidak berjalan dengan efektif. Untuk sosialisasi tidak langsung, dapat disebabkan karena kegiatan sosialisasi tidak langsung relatif singkat serta materi dan informasi perpajakan yang disampaikan cenderung bersifat umum (tidak detail) dan mungkin saja media yang digunakan tidak sesuai dengan kajian atau kurang tepat untuk audience.

Hasil penelitian ini sejalan dengan penelitian yang dilakukan Warouw, (2017) KPP Pratama Manado dan KPP Pratama Bitung yang menyatakan bahwa sosialisasi perpajakan tidak berpengaruh signifikan terhadap kepatuhan wajib pajak karena ketidakpahaman responden atau Wajib Pajak terhadap materi atau informasi perpajakan yang disampaikan.

Namun Hasil penelitian ini tidak sejalan dengan penelitian Pratami, et.al (2017) menyatakan bahwa sosialisasi perpajakan berpengaruh signifikan terhadap kepatuhan wajib pajak karena jika sosialisasi perpajakan disampaikan dengan jelas, benar, dan nyaman oleh petugas pajak maka wajib pajak akan memiliki pengetahuan tentang arti pentingnya membayar pajak yang secara otomatis akan meningkatkan kepatuhan wajib pajak. Semakin sering sosialisasi pajak dilakukan akan membuat wajib pajak menyampaikan SPT tepat waktu, karena adanya sosialisasi perpajakan membuat wajib pajak jadi mengetahui manfaat pajak bagi negara serta mengetahui tata cara perhitungan pajak dengan benar sehingga memberikan kesadaran akan pentingnya manfaat pajak yang membuat wajib pajak secara sukarela menjalankan kewajiban pajaknya.

\section{Pengaruh Penerapan e-SPT, Pengetahuan dan sosialisasi secara Simultan terhadap Kepatuhan wajib Pajak}

Bedasarkan hasil dari pengujian pada uji simultan (Uji F) menunjukan bahwa penerapan e-spt,pengetahuan dan sosialisasi seacar bersama-bersama berpenggaruh terhadap kepatuhan wajib pajak di desa TelukJambe, dengan hasil diperoleh bahwa hipotesis diterima atau 
$\mathrm{H}_{0}$ diterima dan $\mathrm{H}_{4}$ diterima. Hal ini diperkuat dengan hasil statistic pada table 4.29 yang mengahasilkan nilai signifikan sebesar $0,000<0,05$ dang Fhitung berada di daerah penerima didaerah $\mathrm{H}_{0}$.

Bedasarkan dengan table 4.29 diperoleh hasil perhitungan variable penerapan e-spt(x1), pengetahuan(x2), sosialisasi(x3) memperlihatkan bahwa nilai Fhitung 112,122 dan ftabel 2,72maka artinya fhitung $>$ ftabel dengan nilai signifikan yang diperoleh sebesar 0,000 yang berarti nilai tersebut lebih kecil dari 0,05. Hal ini tersebut menyatakan bahwa $\mathrm{H}_{0}$ diterima dan $\mathrm{H}_{4}$ diterima. Sehingga dapat ditarik kesimpulan bahwa terdapat pengaruh penerapan e-spt,pengetahuan,dan sosialisasi secara bersama-sama terhadap kepatuhan wajib pajak.

Tingkat hubungan penerapan espt,pengetahuan dan sosialisasi dilihat dari hasil nilai koefisien korelasi (R) sebesar 0,800 yang artinya bahwa hubungan antar variable independen dengan variable dependen memiliki hubungan yang kuat sebesar $80 \%$. Selain itu, dapat dilihat dari nilai koefisien determinasi yaitu sebesar $80,7 \%$ dan sisanya $19,3 \%$ dipengaruhi oleh faktorfaktor lainya diluar variable independen dalam penelitian ini atau tidak masuk penelitian ini. Semakin banyak warga yang menggetahui tentang e-spt lalu djp giat melakukan sosialisasi makan penggetahuan perpajakan akan meningkatan kepatuhan wajib pajak di desa TelukJambe.

Hasil penelitian ini sejalan dengan penelitian Tene, et.al (2017) yang menyatakan bahwa penerapan espt,pengetahuan dan sosialisasi secara simultan berpengaruh terhadap kepatuhan wajib pajak. Maka dapat ditarik kesimpulan bahwa dalam penelitian ini variable bebas secara bersama-sama berpengaruh terhadap variable terikat. Hal ini sesuai dengan hipotesis bahwa $\mathrm{Ha}$ diterma dan $\mathrm{H}_{0}$ ditolak.

Dan hasil penelitian ini juga sejalan dengan penelitian Pratami, et.al (2017) yang menyatakan bahwa penerapan e-spt,pengetahuan dan sosialisasi secara simultan berpengaruh terhadap kepatuhan wajib pajak. Maka dapat ditarik kesimpulan bahwa dalam penelitian ini variable bebas secara bersama-sama berpengaruh terhadap variable terikat. Hal ini sesuai dengan hipotesis bahwa $\mathrm{Ha}$ diterma dan $\mathrm{H}_{0}$ ditolak.

Hasil penelitian ini tidak sejalan dengan penelitian Tumuli, et.al (2015) yang menyatakan bahwa penerapan espt,pengetahuan dan sosialisasi secara simultan tidak berpengaruh terhadap kepatuhan wajib pajak. Maka dapat ditarik kesimpulan bahwa dalam penelitian ini variable bebas secara bersama-sama tidak berpengaruh terhadap variable terikat. Hal ini sesuai dengan hipotesis bahwa $\mathrm{Ha}$ ditolak dan $\mathrm{H}_{0}$ ditolak.

\section{PENUTUP \\ Kesimpulan}

Berdasarkan dari hasil penelitian yang telah dilakukan oleh penulis mengenai Pengaruh Penerapan eSPT,Pengetahuan, dan Sosialisasi Terhadap Kepatuhan Wajib Pajak survey pada desa TelukJambe melalui analisa dan data statistik dari kuesioner yang disebarkan, dapat diambil kesimpulan penelitian sebagai berikut:

1. Penerapan e-SPT memiliki pengaruh tidak signifikan terhadap kepatuhan wajib pajak pada desa TelukJambe. Dengan demikian, penerapan e- SPT memberikan pengaruh positif tidak signifikan terhadap kepatuhan pajak yang artinya apabila semakin baik penerapan e-SPT maka kepatuhan pajak menjadi semakin baik. 
2. Pengetahuan perpajakan memiliki pengaruh signifikan terhadap kepatuhan wajib pajak pada desa TelukJambe. Dengan demikian, Pengetahuan Perpajakan memberikan pengaruh positif dan signifikan terhadap kepatuhan pajak yang artinya apabila semakin baik Pengetahuan Perpajakan maka kepatuhan pajak menjadi semakin baik.

3. Sosialisasi perpajakan memiliki pengaruh tidak signifikan terhadap kepatuhan wajib pajak pada desa TelukJambe. Dengan demikian, Sosialisasi memberikan pengaruh positif tidak signifikan terhadap kepatuhan pajak yang artinya apabila semakin baik Sosialisasi maka kepatuhan pajak menjadi semakin baik.

4. Dari hasil uji F (simultan) pada variable penerapan e$\operatorname{spt}(\mathrm{x} 1)$,pengetahuan $(\mathrm{x} 2)$, sosialisasi (x3) pada penelitian ini dapat ditarik kesimpulan bahwa terdapat pengaruh penerapan e-spt,penggetahuan dan sosialisasi secara bersama-bersama terhadap kepatuhan wajib pajak.

\section{Saran}

Berdasarkan hasil analisi data dan pembahasan yang telah dilakukan, penulis mengajukan saran sebagai berikut:

1. Penelitian selanjutnya dapat dilakukan di daerah lain yang belum pernah diteliti sebelumnya dengan menambah jumlah responden.

2. Mengenai Penerapan e-SPT, ternyata masih ada wajib pajak yang tidak mengetahui mengenai pembayaran SPT secara electronic dan bahkan tidak mau meggunakan e-SPT sehingga sosialisasi secara meluas mengenai penerapan e-SPT akan timbul kesadaran dan motivasi pada diri wajib pajak untuk memanfaatkan fasilitas e-SPT.

3. Mengenai pengetahuan perpajakan, masih adanya wajib pajak yang kurang mengetahui pengetahuan tentang pajak dan kurangnya tingkat kepercayaan serta enggannya Wajib Pajak menjalankan kewajibannya. Alangkah baiknya DJP melakukan sosialisasi dan memberikan pemahaman kepada wajib pajak tentang pentingnya pengetahuan pembayaran pajak.

4. Mengenai sosialisasi perpajakan, untuk meningkatkan kesadaran wajib pajak dalam meningkatkan kepatuhan wajib pajak dapat dilakukan oleh KPP Pratama Karawang Utara dengan mengadakan sosialisasi kepada masyarakat secara rutin. Sosialisasi yang dilakukan bisa berupa seminar upaya pelatihan atau sosoialisasi perpajakan yang dapat menambah pengetahuan dan pemahaman diri wajib pajak terhadap peraturan perpajakan sehingga dapat membantu meningkatkan sikap sadar membayar pajak agar masyarakat mau untuk membayar pajak. Semakin baik kesadaran wajib pajak yang diterapkan, maka semakin banyak wajib pajak yang patuh memenuhi kewajibannya sebagai wajib pajak.

\section{DAFTAR PUSTAKA}

Anjarwati N \& Robiyanto F. (2017). Pengaruh Sosialisasi, Penerapan E-filling dan Tax Amnesty terhadap Kepatuhan Pajak Studi Empiris Pada Wajib Pajak Orang Pribadi di KPP Pratama Kudus dan Pati . Jurnal 1(1).

Kertahadi \& Handayani S.,R. (2015). Pengaruh Pemanfaatan Aplikasi E-spt Masa PPN Terhadap Tingkat Kepatuhan Wajib Pajak Studi pada Kantor Pelayanan 
Pajak Pratama Surabaya Genteng. Jurnal, 1(1).

Mardiasmo. (2011). Perpajakan Edisi Revisi. Penerbit : Andi Waluyo. Edisi 6 Akuntansi Pajak.Penerbit : Salemba Empat

Pratami, L.,P., K., A., W, Sulindawati N.L.G.E.S, \& Wahyuni, M.A. (2017). Pengaruh Penerpan Esystem Perpajakan terhadap Tingkat Kepatuhan Wajib Pajak Orang Pribadi dalam Membayar Pajak pada Kantor Pelayanan Pajak Pratama Singaraja . Jurnal . 15(1).

Sari N., P, Kertahadi, \& Maria, G.W.N.P. (2015). Pengaruh Penerapan e-SPT terhadap Kepatuhan Wajib Pajak Badan Dalam Melaporkan SPT Studi Kasus Pada KPP Madya Malang . Jurnal, 27(45).

Sugiyono. (2015). Metode Penelitian Kuantitatif, kualitatif $D \cap R$ dan $D$. Bandung Alfabeta

Suharsono A. (2015). Ketentuan Umum Perpajakan : Graha Ilmu

Tene J.,H, Sondakh J.,J, \& Warongan JDL. (2017). Pengaruh Pemahaman Wajib Pajak, Kesadaran Pajak, Sanksi Perpajakan dan Pelayanan Fiskus terhadap Kepatuhan Wajib Pajak Studi Empiris pada Wajib Pajak Orang Pribadi yang Terdaftar di KPP Pratama Manado . Jurnal . 5(2).

Tumuli A., K,Sondakh J., J, Heince R.N. (2015). Analisis Penerapan E-spt dan E-filling dalam upaya Peningkatan Kepatuhan Wajib Pajak Studi Kasus di Kantor Pelayanan Pajak Pratama Manado . Jurnal. 4(3).

Warouw, J., Z., S, Sondakh, J., J, dan Walandouw, S.K. 2015. Pengaruh Sosialisasi Perpajakan dan Sanksi Perpajakan terhadap Kepatuhan Pelaporan Spt Tahunan Wajib Pajak Badan . Jurnal, 3(3). 